Rancang Bangun Alat Penyortiran Barang Otomatis Berbasis Arduino Pada PT Wahana Prestasi Logistik Semarang, Vol 11, No.1, Desember 2018.

\title{
RANCANG BANGUN ALAT PENYORTIRAN BARANG OTOMATIS BERBASIS ARDUINO PADA PT WAHANA PRESTASI LOGISTIK SEMARANG
}

\author{
YAN ILMAS PUIMERA, DANANG DANANG
}

\author{
Sekolah Tinggi Elektronika dan Komputer (STEKOM) \\ Jl. Majapahit 605 \& 304 Semarang, Indonesia Email : \\ humas@stekom.ac.id
}

\begin{abstract}
Abstrak
Tujuan dari penelitian ini untuk membuat desain alat penyortiran barang secara otomatis menggunakan sensor ultrasonik, sensor load cell. Motor servo berbasis arduino yang valid sehinngga produk prototipe alat penyortiran barang secara otomatis yang menggunkan sensor ultrasonik dan sensor load cell berbasis arduino ini dapat diterima pleh PT Wahana Prestasi Logistik Semarang. Adapun metode yang digunakan dalam penelitian ini adalah metode penelitian Reasearch and Development (R\&D dari Borg and Gall. Penelitian ini membahas tentang membangun alat penyortiran barang secara otomatis menggunakan sensor ultrasonik, sensor load cell, motor servo, conveyor dan arduino. Hasil produk akhir yang didapat produk prototipe sudah valid, terbukti dari sensor ultrasonik, sensor load cell mendeteksi ketinggian barang paket, dan berat barang paket maka alat akan menyortir barang secara otomatis dan mengetahui harga yang harus dibayar. Kemudian produk prototipe ini sudah dinyatakan baik dan diterima oleh pengguna (PT Wahana Prestasi Logistik Semarang) melalui validasi pengguna,
\end{abstract}

Kata kunci :Arduino,sensor ultrasonik, sensor load cell, motor servo

\section{Pendahuluan}

Perkembangan ilmu pengetahuan dan teknologi pada zaman modern ini telah mengalami peningkatan yang amat pesat. Keadaan seperti ini menimbulkan imbas yang besar pada semua bidang kehidupan manusia terutama pada bidang bisnis pengiriman barang. Proses ini ditandai dengan persaingan yang semakin ketat antara pelaku usaha dalam memanfaatkan kemajuan teknologi guna mendukung pengembangan masing-masing unit usaha, maka dari itu diperlukan perkembangan teknologi untuk menunjang dalam unit usaha khususnya dalam bidang pengiriman barang, yang saat ini dalam proses penyortiran barang paket masih menggunakan cara manual sehingga dalam proses ini masih terjadi ketidak akuratan dalam proses penyortiran dan membutuhkan waktu yang cukup lama sehingga mengangu untuk proses selanjutnya. Berikut ini alat- alat yang digunakan timbang manual dan pengaris.

PT. Wahana Prestasi Logistik Semarang yang terdapat di Jl. Raya Mangkang KM.15 Semarang adalah sebuah perusahaan yang bergerak di bidang logistik atau jasa pengirimanan barang dan dokumen. perusahaan ini mempunyai 10 cabang di Semarang. Perusahaan tersebut termasuk 
Rancang Bangun Alat Penyortiran Barang Otomatis Berbasis Arduino Pada PT Wahana Prestasi Logistik Semarang, Vol 11, No.1, Desember 2018.

perusahaan yang telah lama menggeluti bidang usaha pengiriman barang dan dokumen dibandingkan perusahaan lain yang sudah terlebih dahulu ada dalam bidang pengiriman barang dan dokumen, proses penyortiran barang di Wahana Prestasi Logistik pada saat ini masih dilakukan secara manual sehingga membutuhkan waktu kurang lebih 5 menit, mulai dari pengukuran berat degan timbangan manual diteruskan pengukuran barang dengan pengaris manual setelah itu di input ke komputer selain dari segi waktu cukup lama, pada saat penyortiran barang yang masih menggunakan cara manual, masih ditemukan terjadi kesalahan dalam menentukan berat barang dan Berikut ini adalah 10 agen PT Wahana Prestasi Logistik Semarang dan 3 sempel agen pengiriman paket barang

\section{Pengertian Rancang Bangun}

Menurut Indahpratama ( 2013 )
Rancang bangun
serangkaian prokedur r untuk
menerjemahkan hasil analisa dari
sebuah sistem ke dalam bahasa pemrograman untuk mendeskripsikan dengan detail bagaimana komponenkomponen sistem diimplementasikan (Pressman, 2002). Rancangan sistem adalah penentuan proses dan data yang diperlukan oleh sistem baru (McLeod, 2002). Perancangan adalah kegiatan yang memiliki tujuan untuk mendesain sistem baru yang dapat menyelesaikan masalah-masalah yang dihadapi perusahaan yang diperoleh dari pemilihan alternatif sistem yang terbaik (Ladjamudin, 2005). Sedangkan pengertian bangun atau pembangunan sistem adalah kegiatan menciptakan sistem baru maupun mengganti atau memperbaiki sistem yang telah ada baik secara keseluruhan maupun sebagian (Pressman, 2002). Bangun sistem adalah membangun sistem informasi dan komponen yang didasarkan pada spesifikasi desain (Whitten et al, 2004).

Dengan demikian pengertian rancang bangun merupakan kegiatan menerjemahkan hasil analisa ke dalam bentuk paket perangkat lunak kemudian menciptakan sistem tersebut ataupun memperbaiki sistem yang sudah ada.

\section{Pengerian Arduino}

Menurut Ariefeeiiggeenn( 2014 ) Arduino adalah pengendali mikro singleboard yang bersifat open-source, diturunkan dari Wiring platform, dirancang untuk memudahkan penggunaan elektronik dalam berbagai bidang. Hardwarenya memiliki prosesor Atmel AVR dan softwarenya memiliki bahasa pemrograman sendiri. Saat ini Arduino sangat populer di seluruh dunia. Banyak pemula yang belajar mengenal robotika dan elektronika lewat Arduino karena mudah dipelajari. Tapi tidak hanya pemula, para hobbyist atau profesional pun ikut senang mengembangkan aplikasi elektronik menggunakan Arduino. Bahasa yang dipakai dalam Arduino bukan assembler yang relatif sulit, tetapi bahasa $C$ yang disederhanakan dengan bantuan pustaka-pustaka (libraries) Arduino. Arduino juga menyederhanakan proses bekerja dengan mikrokontroler, sekaligus menawarkan berbagai macam kelebihan antara lain:

a. Murah - Papan (perangkat keras) Arduino biasanya dijual relatif murah (antara 125ribu hingga 400ribuan rupiah saja) dibandingkan dengan platform 
Rancang Bangun Alat Penyortiran Barang Otomatis Berbasis Arduino Pada PT Wahana Prestasi Logistik Semarang, Vol 11, No.1, Desember 2018.

mikrokontroler pro lainnya. Jika ingin lebih murah lagi, tentu bisa dibuat sendiri dan itu sangat mungkin sekali karena semua sumber daya untuk membuat sendiri Arduino tersedia lengkap di website Arduino bahkan di website-website komunitas Arduino lainnya. Tidak hanya cocok untuk Windows, namun juga cocok bekerja di Linux.

b. Sederhana dan mudah pemrogramannya - Perlu diketahui bahwa lingkungan pemrograman di Arduino mudah digunakan untuk pemula, dan cukup fleksibel bagi mereka yang sudah tingkat lanjut. Untuk guru/dosen, Arduino berbasis pada lingkungan pemrograman Processing, sehingga jika mahasiswa atau muridmurid terbiasa menggunakan Processing tentu saja akan mudah menggunakan Arduino.

c. Perangkat lunaknya Open Source - Perangkat lunak Arduino IDE dipublikasikan sebagai Open Source, tersedia bagi para pemrogram berpengalaman untuk pengembangan lebih lanjut. Bahasanya bisa dikembangkan lebih lanjut melalui pustaka-pustaka $\mathrm{C}++$ yang berbasis pada Bahasa $\mathrm{C}$ untuk AVR.

d. Perangkat kerasnya Open Source - Perangkat keras Arduino berbasis mikrokontroler ATMEGA8, ATMEGA168, ATMEGA328 dan ATMEGA1280 (yang terbaru ATMEGA2560). Dengan demikian siapa saja bisa membuatnya (dan kemudian bisa menjualnya) perangkat keras Arduino ini, apalagi bootloader tersedia langsung dari perangkat lunak Arduino IDE-nya. Bisa juga menggunakan breadoard untuk membuat perangkat Arduino beserta periferal-periferal lain yang dibutuhkan.

\section{Kerangka Berpikir}

Kerangka pikir pada penelitian ini dinyatakan dalam bentuk skema sederhana menurut pokok-pokok penelitian dan hubungannya. Kerangka pikir dalam skema ini diharapkan dapat menggambarkan isi penelitian dan identifikasinya. Sehingga pengolahan sumber data menjadi terarah. Kerangka pikir dari penelitian ini seperti yang di tunjukkan pada gambar

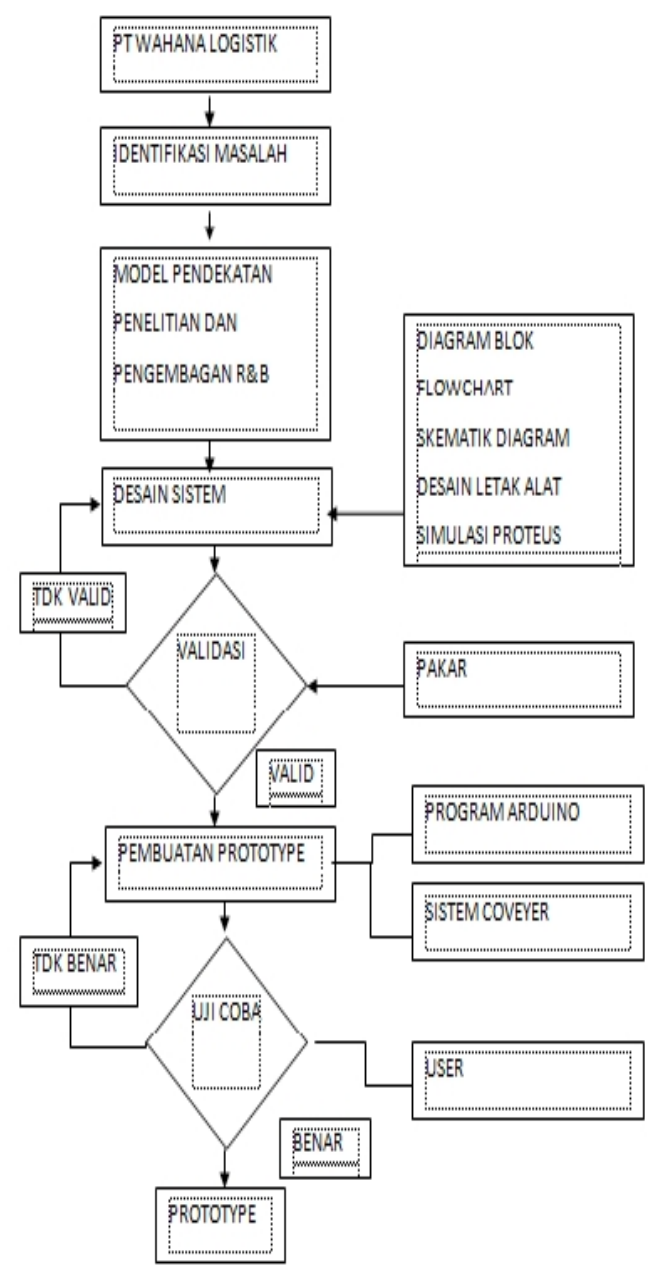


Rancang Bangun Alat Penyortiran Barang Otomatis Berbasis Arduino Pada PT Wahana Prestasi Logistik Semarang, Vol 11, No.1, Desember 2018.

Gambar Kerangka Pemikiran Penulis

\section{Model Pengembangan}

MenurutSygiyono(2016 ) Metode penelitian pada skripsi ini dilakukan dengan pendekatan model penelitian dan pengembangan ( $R$ \& $D$ ) yang dapat diuraikan sebagai berikut :

Model pengembangan diperlukan sebagai dasar pengembangan produk yang mengacu pada model Research and Development (R\&D) dari Borg and Gall. Model R\&D merupakan model rancangan pengembangan desain yang bertujuan untuk mengembangkan dan menvalidasi produk. Pemilihan model Borg and Gall berdasarkan pertimbangan pada model pengembangan yang sudah tersusun dan terprogram dengan langkah - langkah persiapan dan perencanaan yang teliti. Langkah langkah yang dilakukan dalam skripsi ini menggunakan pendekatan model pengembangan $R$ \& $D$ yang hanya mengadopsi 6 (enam) ahapan sa je sebaga i be riku $t$ : (a ) penelitian dan pengumpulan in frmas i, (b ) perencanaan, (c) pengembangan produk, (d) uji apangan awal, (e ) evisi produk utama, (f) uji lapangan lanjut. Adapun bagan tahapan model pengembangan seperti ditunjukkan pada gambar berikut

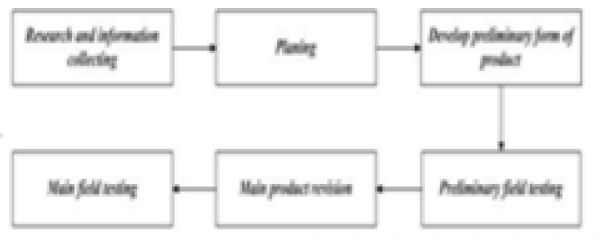

Gambar 3.2.1Moel Pegembangan.
1. Research and information collecting (pengumpulan data)

Penulis mengumpulkan data daninformasi yang dibutukan dengan melakukan wawancara dengan manager dan observasi secara langsung pada PT. Wahana Prestasi Logistik Semarang,sehingga penulis dapat mengetahui permasalahan yang ada di tempat penelitian tersebut untuk dijadikan bahan penulisan dan menjadi acuan untuk membuat rancang bangun alat penyortiran barang otomatis. Oleh karena itu dibuat suatu kerangka piker sebagai pemecahan masalah yang ada padat empat penelitian dimana kerangka piker harus tetap mengacu pada kajian teori dan model pengembangan yang telahditentukan

\section{Planning (perancangan)}

Setelah penulis menemukan masalah yang ada pada tempat penelitian, peneliti menyusun desain rancangan sistem yang sesuai dengan kebutuhan di obyek penelitian meliputi tujuan sistem, spesifikasi produk, dan jadwal kegiatan penelitian.

3. Develop andpremilinary form of product (desain produk)

Desain produk diwujudkan dalam bentuk bagan atau gambar, sehingga dapat digunakan sebagai pegangan untuk menilai atau membuatnya. Desain produk dilakukan untuk mengetahui tampilan awal atau rancangan produk yang akan dikembangkan oleh penelitiyaitu diagram blok, flowchart, skematik diagram, desain letak alat, simulasi proteus.

\section{Premiliary field testing (validasi desain)}


Rancang Bangun Alat Penyortiran Barang Otomatis Berbasis Arduino Pada PT Wahana Prestasi Logistik Semarang, Vol 11, No.1, Desember 2018.

Tahap uji validasi desain merupakan proses untuk menilai apakah produk sesuai kebutuhan atau tidak. Kemudian, untuk mengetahui kelemahan dan kelebihan produk yang dikembangkan. Validasi desain dilakukan oleh tenaga ahli yaitu dosen yang berkompeten, validasi dilakukan sampai hasilnya valid.

5. Main Product Revison (revisi desain) Setelah validasi desain, dilakukan revisi desain untuk mencari apakah masih ada ketidaksesuaian atau kesalahan pada produk agar diperbaiki dan sebagai penyempurnaan produk yang akan dikembangkan. Pada tahap ini peneliti memperbaiki kembali desain produk yang belum valid berdasarkan saran perbaikan dari validasi desain.

\section{Main field testing (uji coba} lapangan )

Setelah desaindinyatakan valid olehpakar, dibuat prototype produk yang kemudian dilakukan ujicoba lapanganpada lokasi obyek penelitian di PT. Wahana Prestasi Logistik Semarang.

\section{Hasil}

Setelah melakukan validasi desain yang melibatkan pakar ahli dan uji coba produk oleh pengguna,berikut adalah hasil pengembangan sistem yang dibangun oleh penulis berupa produk prototipe, peneliti melakukan pengujian awal dengan merangkai semua komponen dan sensor pada prototipe,kemudian sistem alat dihidupkan. Apabila sistem berjalan dengan baik maka Icd pada prototipe yang sudah di buat akan ada perintah masukan barang paket,itu menandakan bahwa alat sudah siap di gunakan

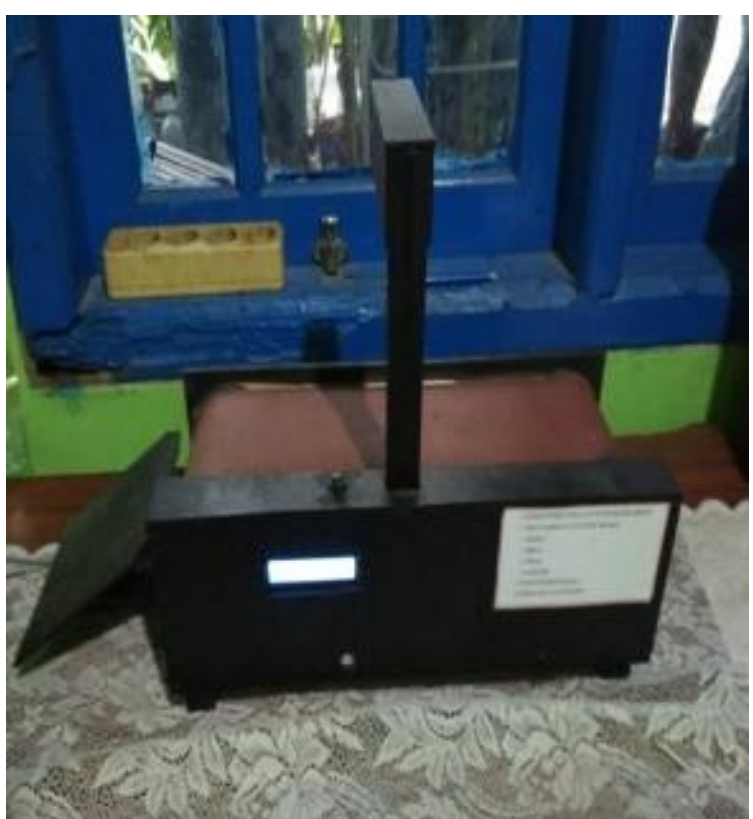

Gambar 4.2.1 Tampilan Prototipe Alat

Setelah alat siap digunakan langkah selanjutnya hidupkan alat dengan cara mencolokan steker pada terminal listrik maka alat akan otomatis On.

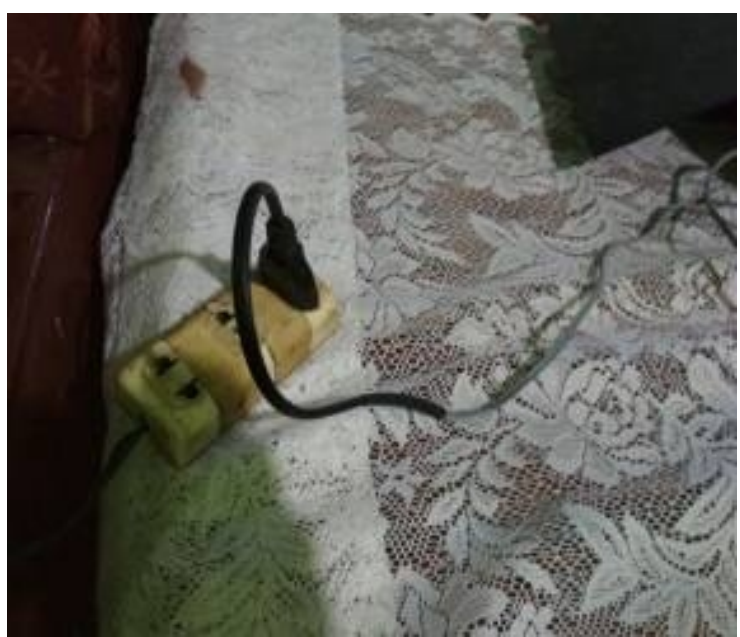

Gambar 4.2.2 Proses Mengidupakan Alat

Setalah melakukan uji coba pengukuran tinggi dan berat barang dengan cara manual, langkah selanjutnya pengujian produk pada gambar di bawah ini adalah proses pengukuran tinggi dan 
Rancang Bangun Alat Penyortiran Barang Otomatis Berbasis Arduino Pada PT Wahana Prestasi Logistik Semarang, Vol 11, No.1, Desember 2018.

berat dengan sensor yang terdapat dalam produk yang dibuat.

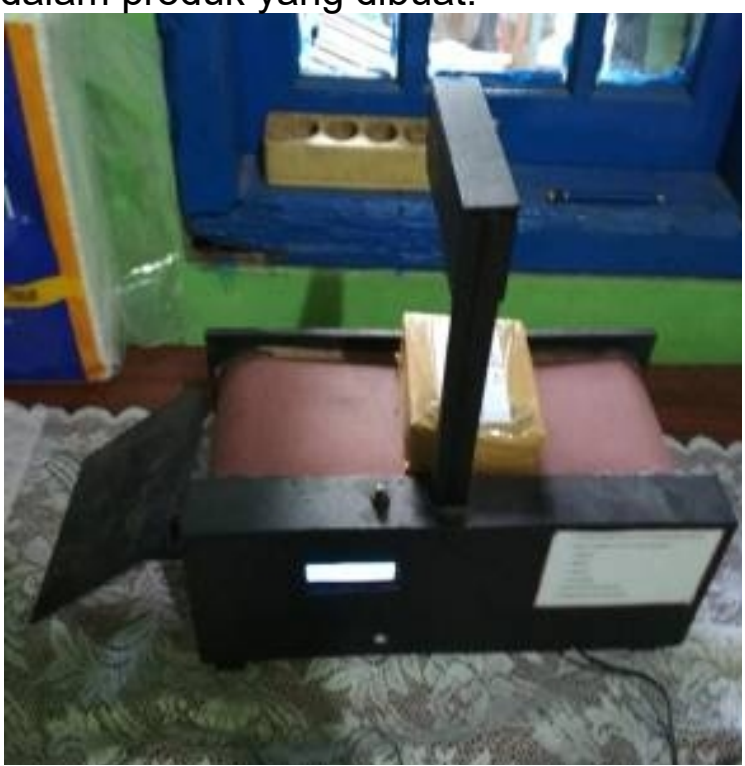

Gambar 4.2.6 Uji Coba Alat

\section{Kesimpulan}

Berdasarkan hasil analisis data pada pengembangan produk alat penyortiran barangyang dilakukan di PT Wahana Prestasi Logistik Semarang, bahwa kerja sistem lama yang menggunakan penyortiran barang dengan cara manual yaitu mengukur tinggi barang paket dengan penggaris dan mengukur berat dengan timbangan buah atau timbangan jarum dan menyortir barangsecara manual dengan cara memilih barang dengan tenaga manusia yang masih terdapat kesalahan penyortiran.

Setelah dibangun sistem baru yang telah melalui pengujian desain oleh pakar dan juga uji coba prototipe oleh user, prototipe sistem penyortiran barang secara otomatis berbasis arduino yang telah di kembangakan dinyatakan layak untuk dikembangakan lebih lanjut menjadi aplikasi yang sebenarnya di PT Wahana Prestasi Logistik Semarang karena telah memenuhi beberapa kebutuhan penyortiran barang sebagai berikut:

a. Mampumelakukan mengukur ketinggian paket barang secara otomatis dengan cara meletakan paket barang di atas coveryor belt lalu alat akan berjalan menuju sensor ultrasonic setelah terbaca oleh sensor maka akan muncul hasil tinggi paket barang secara otomatis ke lcd

b. Mampu melakukan penghitungan harga paket barang secara otomatis dengan rumus tinggi paket barang ditambah berat paket barang yang muncul pada layar lcd

c. Mampumelakukan penyortiran barang secara otomatis dengan cara setelah meletakan barang paket barang di atas coveyor belt alat akan berjalan menuju sensor ultrasonic dan sensor load cell dan akan membaca hasil tinggi, berat dari sensor dan akan menentukan barang paket termasuk kriteria kecil,sedang atau besar jika paket barang paket termasuk kriteria kecil maka motor servo akan bergerak kekanan,jika kriteria barang paket sedang motor servo akan bergerak ketengah sedangkan jika barang termasuk kriteria besar maka motor servo akan bergerak ke kiri

Sehingga dengan demikian tujuan dibangunya sistem penyortiran barang secara otomatis ini telah memenuhi kebutuhan penyortiran di PT Wahana Prestasi Logistik Semarang dan dapat dikembangkan lebih lanjut menjadi aplikasi yang nyata.

\section{Daftar Pustaka}

Ardi Al-Maqassary,2014 Pemanfaatan PLC untuk mengendalikan peralatan penyortir.

Ariel (2011); “ Rancang Bangun Prototype Sistem Aktuator Sirip 
Rancang Bangun Alat Penyortiran Barang Otomatis Berbasis Arduino Pada PT Wahana Prestasi Logistik Semarang, Vol 11, No.1, Desember 2018.

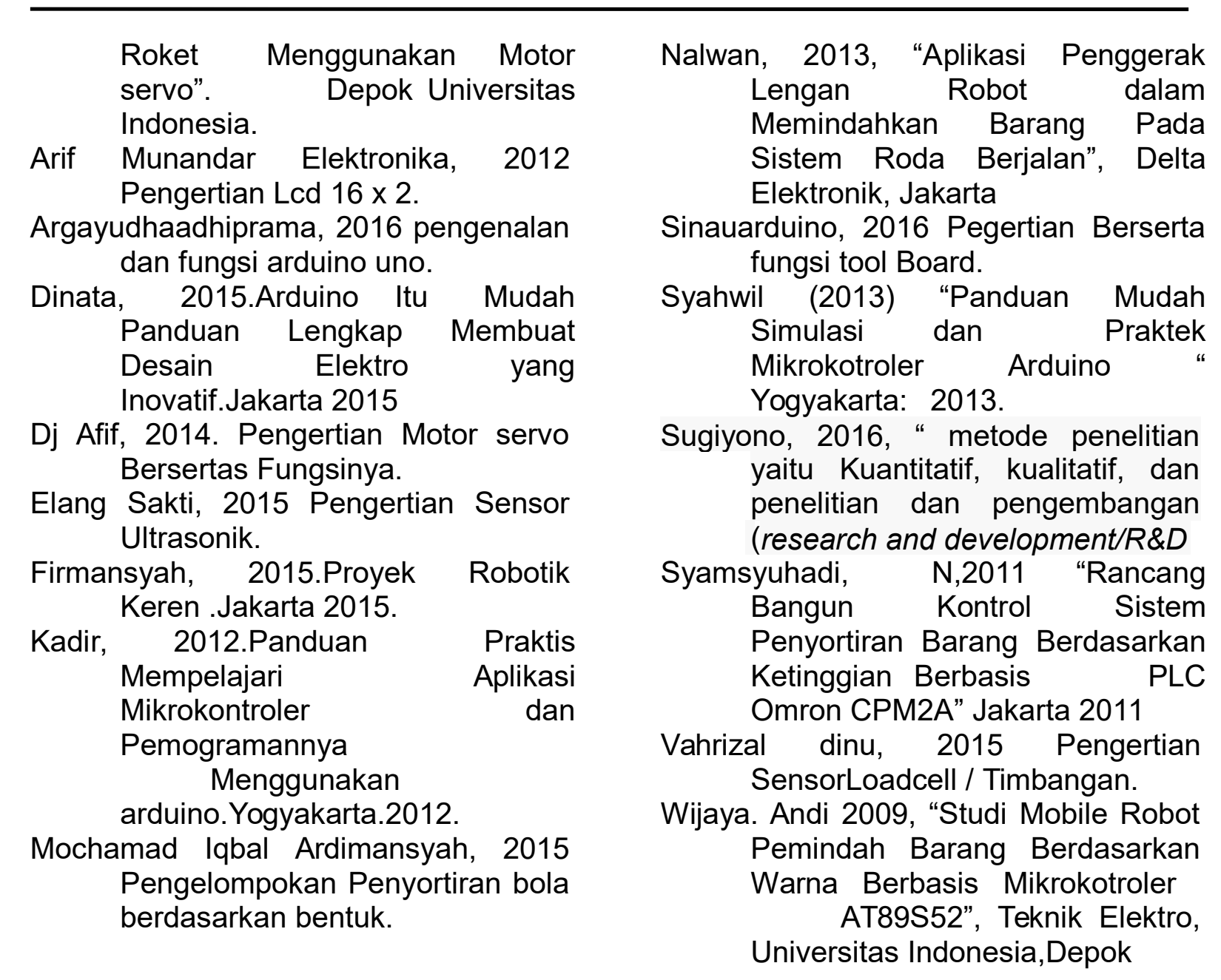


